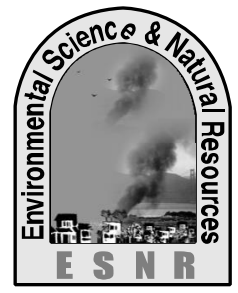

\title{
Scarcity of Safe Drinking Water in the South-West Coastal Bangladesh
}

\section{A. Rahman ${ }^{1 *}$ and M. N. Islam ${ }^{2}$}

${ }^{1}$ Department of Geomatics, Patuakhali Science and Technology University, Bangladesh

${ }^{2}$ Department of Geography and Environment, Pabna University of Science and Technology, Bangladesh

*Corresponding author: ashiq.geo.bd@gmail.com

\begin{abstract}
This study incorporates a detail exploration of drinking water scarcity in the south-western coastal area of Bangladesh. The objectives were to recognize the constraints of potable water supply in the coastal area and to identify the water-scarce area of a coastal community of Bangladesh. Both primary and secondary data have been used to carry out the study. A total of 349 households were selected by using appropriate statistical procedure. ArcGIS has been used for pertinent mapping and calculating the served and unserved (inadequate supply) area of the nearest community water source e.g. pond sand filters or tube-wells. This study found that the root causes i.e. saline water intrusion, reduction of upstream flow, sea level rise, disasters, polder, arsenic contamination, shrimp cultivation in brackish water, excessive use of underground water and lack of appropriate aquifer were highly influential for the disturbance of potable water supply in the coastal area. In addition, it has been showed that about two-third of the settlement areas as well as households fell into the water scarce zone.
\end{abstract}

Key words: Potable water, Served household, Water scarcity

\section{Introduction}

Water is a fundamental resource for life and livelihood. The distribution, allocation, and management of water resource remain a noteworthy concern being improvement considerations and practices for quite a long time. Especially, in many water-stressed regions of the world, it plays a vital role in social, financial and political strategies (Arsel and Spoor, 2009). Access to safe drinking water is a basic well-being and financial advancement issue at national, regional and local levels (World Health Organization, 2011; Cvjetanovic, 1986). All around one out of seven individuals has needed access to even least supplies of safe drinking water to fulfil their fundamental personal and residential needs. Several millions are left with no decision, however stroll for a considerable length of time to gather water from hazardous sources, for example unprotected well, streams or lakes utilized by animals (WASH United, Freshwater Action Network and WaterLex, 2012). The worldôs population is expected to reach eight billion by 2025, growing demands on drinking water supplies and water for food production are evident, and competing uses of limited resources are inevitable (UNDP, 2006).

Creditable achievement has been accomplished over most recent couple of decades in giving safe drinking water, but mostly withdrawing groundwater in Bangladesh. Yet in the recent years, groundwater based water supply in the coastal areas have been experiencing various significant issues, principally arsenic sullying, bringing down of the water table, salinity and unavailability of reasonable aquifers (PDO-ICZMP, 2004). The extent of utilizing and improved drinking water source was $97.9 \%$ in $2012-13,98.5 \%$ in 2013 and $86.9 \%$ in 2015 (Bangladesh Bureau of Statistics, 2014; BBS, 2015; World Bank, 2016). Lack of safe drinking water has been identified as the number one issue in the daily life of the coastal population (Islam and Ahmad, 2004).

Arsenic and saline contamination make difficulties for supplying potable water to the underprivileged people of the country. The poor and destitute people cannot bear the cost of water technologies due to the financial crisis. Another measurement of hard to reach areas is the shortage of land for establishing the water technologies as they live on a small piece of land on street or embankment. In such cases, in spite of having the ability, individuals canâ ensure safe water for themselves (NGO Forum for Public Health, 2012). In the coastal areas of Bangladesh, the deficiency of drinking water is intense as the freshwater aquifers are not available at reasonable depths and the surface water is profoundly saline and turbid (Islam et al., 2014). Shrimp farming has been increased over the past two decades by essentially changing the local land use, and adversely influencing surface and groundwater resources (Datta et al., 2010). WHO (2004) found that the groundwater is inadmissible for human consumption due to high salinity in the south- 
western region of the country (Khulna, Satkhira and Bagerhat district). Further, Ali (2006) reported that, saline water intrusion has caused issues in terms of severely declining the supply of potable water. Both surface and groundwater have been polluted by saline in this area. For this, rainwater is the most suitable for meeting drinking water needs. Islam (2015) also reported that rain water harvesting system (RWHS) is an important innovative livelihood option for safe drinking water in the exposed salinity-prone coastal area. The dwellers can collect water in monsoon and use for next five months in drought season only for drinking purpose.

However, the issue is about conservation. The dwellers reserve rainwater in a plastic tank, mutki (earthen big jar) or cemented tank (if available). UNICEF and Union (lowest administrative unit of local government) Council have found that nearly half $(52.64 \%)$ of the households has an access to safe drinking water in Kamarkhola Union of Dacope Upazila (sub-district) under Khulna District (UISC, 2016). But, this less amount can serve few months hardly. People of this area mainly consume water from pond sand filter (PSF) and a little number of tube well (hand pump deep tube-well), where the presence of sweet or tolerable saline layer of water. The potable water supply from PSF is an important community source in the coastal area of the country (Moniruzzaman and Rahman, 2011; Moniruzzaman et al., 2012). The PSFs donâ function properly round the year due to the lacking of water supply and other functional problems. Most of the dwellers use pond water for their drinking purpose by mixing with alum (potassium aluminium sulfate), without thinking about the purity. Hence, the objectives of this study are to deliberate the constraints of drinking water supply in the coastal area and to identify the water-scarce area of a coastal community of Bangladesh.

\section{Methodology}

\section{Data collection}

Both primary and secondary data were employed in this study. Together qualitative and quantitative approaches were applied for data collection, analysis, and presentation. In this study, a Union, called Kamarkhola of Dacope Upazila under Khulna District was selected. The constraints of safe water supply have been identified by reviewing different published and unpublished documents. After that, the suitable water access (served) area has been determined by questionnaire survey and field observation. Total 349 households were selected from the total 3,727 households of the study area, using the appropriate statistical procedure. Where, the confidence level was 95\%, margin of error 5\% and response distribution 50\%. PSFs and tube-wells were considered among all the community water sources. The secondary data were collected from relevant research articles, publications from different organizations, books etc. Further, ArcGIS 10.0 has been used for preparing the relevant maps. Moreover, Global Positioning System (GPS) was used to identify out the distribution of water supply technologies and selected households.

\section{Study area}

Dacope Upazila comprises an area of $991.58 \mathrm{~km}^{2}$, is bounded by Batiaghata Upazila on the north, Pashur River on the south, Rampal and Mongla Upazila on the east, Paikgachha and Koyra Upazila on the west. Main rivers are the Pasur, the Shibsha, the Manki and also the Bhadra. The study area, Kamarkhola Union, lies between $22^{\circ} 52^{\prime}$ to $22^{\circ} 56^{\prime}$ north latitude and $89^{\circ} 24^{\prime}$ to $89^{\circ} 30^{\prime}$ east longitude covering an area of $29.2 \mathrm{~km}^{2}$. Kamarkhola along with Sutarkhali emerge as polder number 32 of Bangladesh Water Development Board (Fig. 1). There are 3,727 households comprising total 15,407 population including 7,389 men and 7,418 women in the study area. Population density is 527 per $\mathrm{km}^{2}$. The literacy rate is $47.0 \%$ (UISC, 2016). 


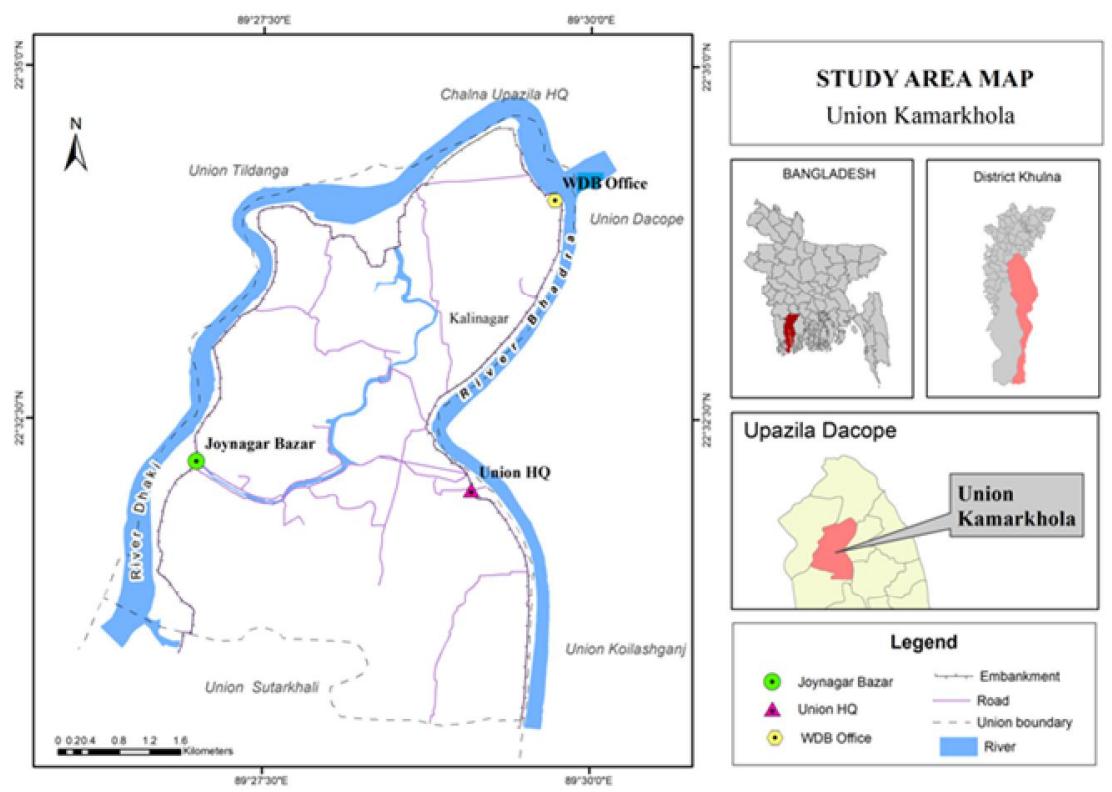

Fig. 1. Location of the study area

\section{Results and Discussion}

\section{Root causes of water-scarcity in the coastal area}

Water plays a crucial role for improving human wellbeing (Crow and Sultana, 2002). It is considered óafeô when itôs free from pathogenic agents, and harmful chemical substance, and satisfying to taste i.e. ideally free from colour and odour, and usable for domestic purposes (Park, 2015). Scarcity of water must be comprehended by considering the whole measurement. Firstly, water is a sustainable asset and its accessibility relies upon the hydrological cycle. Secondly, scarcity of water is temporal and diurnal. Thirdly, there are distributional and social parts of water shortage. The fourth dimension is characterized as the anthropogenic (political, social and institutional) measurement that highlights the intervention and management practices (Mehta, 2003). The importance of institutional and political factors and conjointly emphasizing on the difference in availability and accessing water for explicit users are helpful in understanding the context of freshwater deficiency in the coastal area and therefore the contestation of saline water and fresh water (Alamgir, 2010). The primary reasons for the expansions if salinity and freshwater shortage in the south-western coastal region are the withdrawal of water from major rivers in the upstream and siltation on the river bed, drainage congestion and water logging caused by the improper polder management (Islam and Kibria, 2006). A number of causes have been identified to examine the difficulties of supplying fresh water i.e. saline water intrusion, reduction of upstream flow, sea level rise, disasters, polder, arsenic contamination, brackish shrimp cultivation, excessive use of underground water in an unplanned way, lack of appropriate aquifer etc.

\section{Saline water intrusion}

Potable water is most likely going to become up a serious issue especially in the coastal area due saline water intrusion (NGO Forum for Public Health, 2012). A natural appalling situation caused by saline water instruction is a noteworthy issue and that renders the groundwater unfit for consumption in south-western coastal region of Bangladesh (Ahmed, 2006; NWPo, 1999). It owing to decrease of freshwater spill out of upstream (mostly inferable from the establishment of the Farakka Barrage on the Granges River, near the border of Bangladesh) is required to be irritated by climate change and sea level rises, that has brought about the saline water intrusion being pushed further toward the north (Nicholls et al., 2007). The effect of saline water intrusion is highly seasonal while minimum during the monsoon when the GBM (the Ganges, Brahmaputra and Meghna) Rivers release around $80 \%$ of the annual freshwater flow. In the winter months, the saline water starts to penetrate inland and the influenced regions rise forcefully from $10 \%$ in the monsoon to more than $40 \%$ in the dry season (DMB, 2000). 


\section{Reduction of upstream flow}

Reduction of the stream flow of the River Ganges happens (the Ganges along with the Padma is the largest river system that flows over Bangladesh) in dry season due to over withdrawal of water in the upstream. India diverts at least 40,000 cusecs water through a feeder canal from the Farakka Barrage to the River Hugli to ensure proper navigation at Kolkata port. The flow through the River Gorai, the perpetual distributaries of the River Ganges has been declining since the mid-1970s and the dry season flow has quit from the end of 1980s. This has already risen up the salinity level of the water in Khulna and the Sundarbans (the largest mangrove forest in the world). It has additionally increased salinity in the River Balashar and associated rivers and canals of the country (CEGIS, 2003; Tran and Shaw, 2012). During dry season, a mix of extremely low flow and increased salinity quickened the procedure of sedimentation in the river bed, which eventually stifled the river and radically lessened its drainage capacity. This is the manner by which drainage congestion turned into a usual nature of that river, consequently in the overbank spillage during each peak season. Thus, the area becomes waterlogged for a certain period of the year (Ahmed, 2008).

\section{Sea level rise}

Sea level rise due to global warming continued sedimentation of the rivers and floodplains and subsidence of the Ganges basin are all factors those might result to raise the sea level with respect to land. It has been estimated that the increase of mean sea level from 4.5 to $23.0 \mathrm{~cm}$ by 2025 and from 6.5 to $44.0 \mathrm{~cm}$ by 2050 (NWMP, 2001). The rising sea level will create new salinity affected areas, which might generate further scarcity of potable water.

\section{Disasters}

The south-western region of Bangladesh often experiences to natural disasters (e.g. water logging, cyclones, tidal surges, floods, river erosion etc.) which are responsible for the decimation of drinking water sources. The annual recurrence of disasters is 6.11, making Bangladesh the prominent disaster prone countries of the world. The country receives the end of about two-fifths of the worldôs total impact from storm surges (Murty and El-Sabh, 1992; World Bank, 2005). During and immediately after cyclone AILA (hit on 25 May, 2009), all freshwater sources were contaminated with dirty saline water. Supply of drinking water became the most striking challenge and people were forced to drink that unsafe water in the affected area (Kumar et al., 2010; Haque et al., 2010; Halder and Zaman, 2010).

\section{Polder}

Bangladesh is shaped by the deltaic processes and the formation of its significant south-western coastal part is yet active (Agarwal et al., 2003). A total of 123 flood control polders including 5,107 km of embankment have been constructed covering approximating 1.5 million ha of the coastal area under the Coastal Embankment Project to prevent tidal flooding. Among them, about one million ha lies in the south-western part (Islam et al., 2006; Guimaraes, 2002; Chowhury and Rasul, 2011). The polder/enclosure systems disconnected the lowlands from the rivers (Haq, 2000). Because of the construction of the polders on both sides of the rivers, the natural process of tidal inundation was stopped and resulting into water logging as well as drainage problem caused by the rising of channel bed due to siltation. During the dry season, accumulation of salt in the topsoil through capillary action is gradually increasing the salinity in the areas which were formerly wetlands (Islam and Kibria, 2006; Haq, 2000).

\section{Arsenic contamination}

Severe arsenic tainting of groundwater has disrupted the idea of using shallow tube-wells for safe drinking water throughout the country (Safiuddin and Karim, 2003). The southwest coastal region has been facing for the crisis of pure drinking water due to arsenic contamination in groundwater. However, the number of arsenic affected rural villages is lower than the saline affected villages in the coastal area. (Harun and Kabir, 2013; Rahman et al., 1997; Uttran, 2003; WHO, 2004).

\section{Cultivation of brackish water shrimp}

Shrimp cultivation in brackish water is a serious concern which allowing saline water intrusion into the adjacent agricultural land, groundwater acquirer and waterways in the coastal area of the country (Flaherty et al., 2000). This salinization process reduces fresh water supplies not only for agriculture but also for drinking and domestic needs (Deb, 1998; Patil and Krishnan, 1998).

\section{Excessive use of underground water in an unplanned way}

The absence of surface water for irrigation during dry season has constraints to the agriculturists to exploit underground water extensively leading to a lowering water table beyond the suction limits of shallow tubewell, making millions of shallow tube-wells 
dysfunctional. This over-extraction of groundwater is one of the possible reasons for the contamination of shallow aquifer (Setu et al., 2014). In addition, thousands ha of land has been being irrigated based on groundwater for rice cultivation since last few decades.

\section{Lack of appropriate aquifer}

Groundwater stores in impervious layers due to porous geological arrangements in the upper soil strata. For extraction of groundwater, medium sand is suitable. This sand has considerable porosity and can store a huge of water. Fine sand also can store a considerable amount of water. However, as the study area situated in the lower parts of the Ganges delta, the sediments of the region have very low permeability and donâ seem to be able to store water (NWRPo, 1999). Moreover, Department of Public Health and Engineering (DPHE) officials of Dhaka said that the underground permeable layer of the study area isnâ suitable for using as potable water due to having much fine sand. In some areas, tube-wells are not successful especially in the coastal belt because of saline water intrusion in the aquifer to a depth of 700-1000 feet (DPHE and UNICEF, 1989). Although, deep tube wells provide a relatively reduced level of saline water in the coastal areas but containing sand makes it undrinkable (Ahmed, 1996).

\section{Identification of potable water scarce zone in the study area}

Accessibility to potable water within a suitable distance is a common problem in the coastal area of Bangladesh. Another means of scarcity is inadequate supply of water. In the study area, there are total 28 community water sources for drinking purpose. Among them 15 were PSFs and 13 tube-wells. Though, there have a debate about the quality and uninterrupted supply over the year from those sources. Distance from the sources is an important matter of water collection. Though, the criterion of Bangladesh government is having the safe drinking water source should be within 50 meters of household premise (GoB, 2005).

\section{Distance of water source point from household}

Collection of drinking water from a far distance is the main problem in the coastal area. Generally, the family members mainly housewives collect drinking water from another part of the village or from another village. The actual distance of the nearest water source from each household was determined in between the comparison of the userôs reply and the authorôs observation. From the total households $(\mathrm{n}=349), 94.84 \%(\mathrm{n}=331)$ collect water from outside their house and rest $5.16 \%(n=18)$ have access inside the homestead (they usually depend on rainwater).

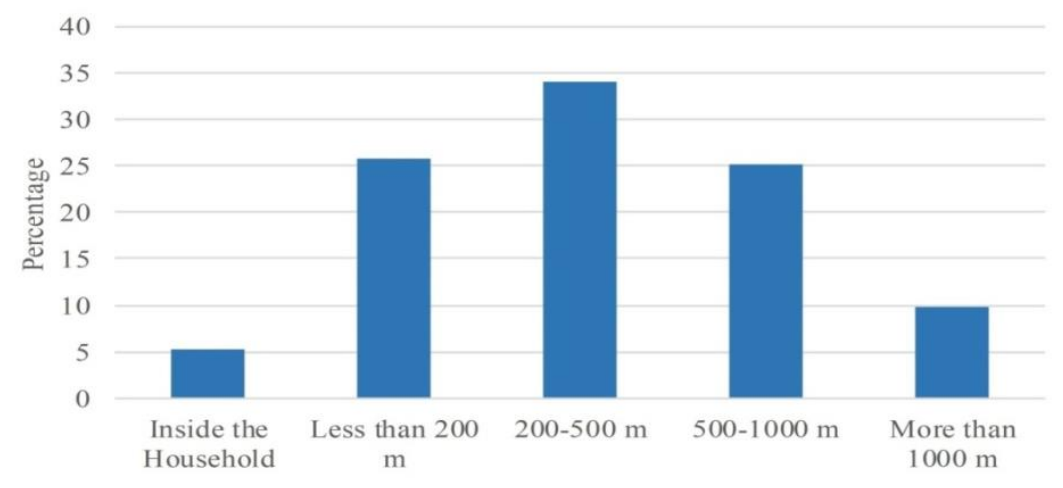

Fig. 2. Distance of the nearest water sources from the household premise

Among them (who collect water from outside the homestead), maximum $34.1 \% \quad(\mathrm{n}=119)$ households collect water from 200 to 500 meter $(\mathrm{m})$ range. Where, $25.79 \%(\mathrm{n}=90)$ answered about less than $200 \mathrm{~m} ; 25.21 \%$ $(\mathrm{n}=88)$ from 500 to $1000 \mathrm{~m}$ and $9.74 \%(\mathrm{n}=34)$ more than $1000 \mathrm{~m}$ (Fig. 2). Actually, the accessibility to the water source was a perception study. A question was asked of each respondent that they face any problem to collect water from the nearest source or not. Among the 349 households, about $63.04 \%(\mathrm{n}=220)$ respondents replied that they face problem in water collection from this distance.

\section{Inadequate water collection}

The suitable area of water supply is that, where the people can collect sufficient water without facing any trouble. Threshold area of water supply from existing 
sources is determined by the buffer of expected distance from the households. Among the total 220 households, the respondents were asked regarding their suitable or desired distance for water collection (Table 1). They choose minimum $50 \mathrm{~m}$ from their household premise. In fact, as it was a comparative study and the distance was determined after combing the decision of the respondent and the authors.
Table 1. Suitable Distance of Water Collection from Household

\begin{tabular}{ccc}
\hline $\begin{array}{c}\text { Distance } \\
\text { (meter) }\end{array}$ & $\begin{array}{c}\text { Frequency }(\mathbf{n}= \\
\mathbf{2 2 0})\end{array}$ & \%age \\
\hline 100 & 80 & 36.36 \\
150 & 21 & 9.55 \\
200 & 119 & 53.09 \\
\hline
\end{tabular}

Based on the observation, $200 \mathrm{~m}$ was determined as the suitable distance of water collection from the homestead. Based on this statement, adequate water accessible area was identified using $200 \mathrm{~m}$ radios from each water points. It is need to mention that only homestead areas were considered during the demarcation.

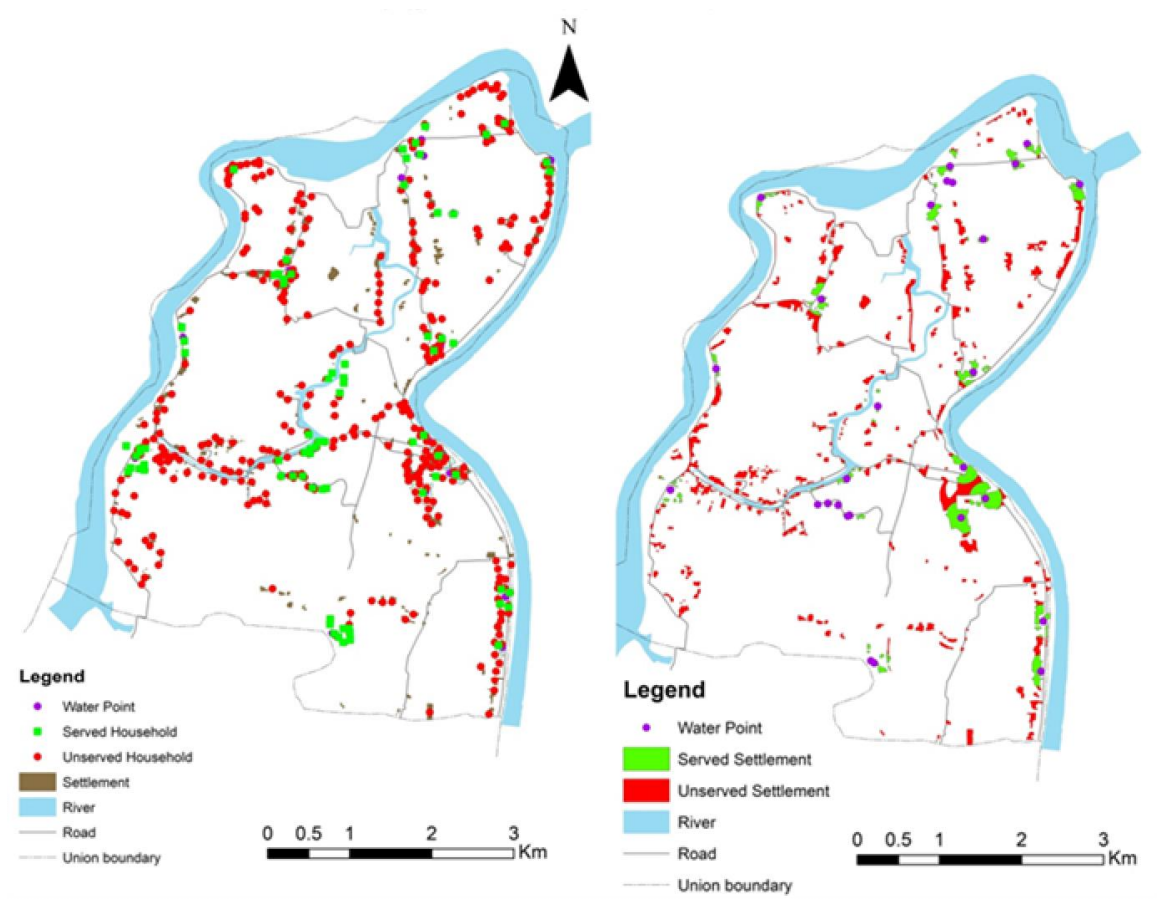

Fig. 3. Identification of the water scarce zone of the study area

The result showed that $67.7 \%$ settlement (homestead) area has laid under water scarce zone (Fig. 3). That means, a significant portion of the settlement areas exist within the suitable water accessible zone. The surveyed households have also been included in this study. The total surveyed 349 households have been calculated in two different types. Among the households, $67.62 \%$ have laid within water scant zone. The result showed that a considerable portion of the study area were beyond the adequate water access (Fig. 3). Hence, the study found the similar, two-thirds of scarcity of in context, settlement area and number of households.

\section{Conclusions}

Potable water is basic for life. The people of this area are facing acute problem for safe drinking water. This study presents a detailed investigation of potable water scarcity in a coastal community of Bangladesh. A number of root causes, those create the difficulties for safe drinking water supply has been identified in this area. The constraints to potable water supply have been incorporated by reviewing relevant literatures. The water-scarce area has been calculated where the potable water supply is not suitable for collection. It was a twodimensional study including the dwellers opinion of the suitable distance from their households and the spatial 
existence of the nearest water source from the homestead area. The factors from reviewed literatures showed that those are highly persuasive for the limitation of potable water supply. The result also showed that a significant part (about two-thirds) of homestead area and a considerable number of households are beyond the suitable water zone, formulated by authorôs observation. The groundwater is not feet for consumption in most of the parts of this area. Moreover, the surface water use is more suitable in environmental sustainability perspective. Some suggestions have also been recommended to work out this drastic condition of suitable drinking water shortage e.g. the existing PSF should be made proper functional by taken appropriate initiatives, the use of rainwater can be increased by the installation of more RWHS, and PSF can be installed on the reserve ponds, make assurance the quality of supply water.

\section{References}

Agrawala, S., Ota, T., Ahmed, A.U., Smith J., and Aalst, M. 2003. Development and climate change in Bangladesh: Focus on coastal flooding and the Sundarbans. Organization for Economic Cooperation and Development, Paris, France.

Ahmed, A.U. 2006. Bangladesh climate change impacts and vulnerability. Climate Change Cell, Department of Environment, Comprehensive Disaster Management Programme, Government of the Peopleôs Republic of Bangladesh, Dhaka, Bangladesh.

Ahmed, A.U. 2008. Desakota phenomenon observed in Satkhiraï Khulnaï Jessoreï Dhaka corridor in the southwestern Bangladesh. Part II F1 of Desakota Study Team 2008, Centre for Global Change, Dhaka, Bangladesh.

Ahmed, M.F. 1996. Coastal water supply in Bangladesh. In: J. Pickford, et al. (Eds.), Reaching the unreached: Challenges for the 21st century. Proceedings of 22nd Water, Engineering and Development Centre (WEDC) International Conference. pp. 165-168, New Delhi, India.

Alamgir, F. 2010. Contested waters, conflicting livelihoods and water regimes in Bangladesh. Masterôs Thesis. Institute of Social Studies, Hague, Netherlands.

Ali, A.M.S. 2006. Rice to shrimp: Land use/land cover changes and soil degradation in southwestern Bangladesh. Land Use Policy, 23: 421-435. DOI:https://doi.org/10.1016/j.landusepol.2005.0 2.001
Arsel, M., and Spoor, M. 2009. Political ecology of marshland restoration in Iraq. In: M. Arsel and M. Spoor (Eds.), Water, environmental security and sustainable rural development: Conflict and cooperation in Central Eurasia. Routledge, Abingdon.

Bangladesh Bureau of Statistics (BBS). 2014. Bangladesh: Multi indicator cluster survey (MICS) 2012-2013. Bangladesh Bureau of Statistics, Statistics and Informatics Division, Ministry of Planning, Government of the Peopleôs Republic of Bangladesh.

BBS. 2015. Report on sample vital registration system (SVRS) 2013. Bangladesh Bureau of Statistics, Statistics and Informatics Division, Ministry of Planning, Government of the Peopleôs Republic of Bangladesh.

CEGIS. 2003. Analytical framework for the planning of đ́ntegrated water resources managementô Center for Environment and Geographic Information Services (CEGIS), Version 2.0., Dhaka, Bangladesh.

Chowhury, A.K.M.J.H., and Rasul, G. 2011. Equity and social justice in water resource governance: the case of Bangladesh. South Asian Water Studies, 2(2): 45-58.

Crow, B., and Sultana, F. 2002. Gender, class and access to water: three cases in a poor and crowded delta. Society and Natural Resources, 15(8): 709-724. DOI: 10.1080/08941920290069308

Cvjetanovic, B. 1986. Health effects and impact of water supply and sanitation. World Health Statistics Quarterly, 39(1): 105-117.

Datta, D.K., Roy K., and Hassan, N. 2010. Shrimp culture: trend, consequences and sustainability in the south-western coastal region of Bangladesh. In: A.L. Ramanathan, P. Bhattacharya, T. Dittmar, M.B.K. Prasad and B.R. Neupane (Eds.), Management and sustainable development of coastal zone environments, pp. 227-244. Springer, Dordrecht.

Deb, A.K. 1998. Fake blue revolution: environmental and socioeconomic impacts of shrimp culture in the coastal areas of Bangladesh. Ocean Coast Management, 41: 63-88. DOI: https://doi.org/10.1016/S0964-5691(98)00074$\mathrm{X}$

DMB. 2010. National plan for disaster management 2010ї 2015. Disaster Management Bureau 
(DMB), Government of the Peopleâs Republic of Bangladesh.

DPHE and UNICEF. 1989. A report on the development of pond sand filtration. Department of Public Health Engineering, Dhaka, Bangladesh.

Flaherty, M., Szuster, B., and Miller, P. 2000. Low salinity inland shrimp farming in Thailand. Ambio, 29(3): 174-179. $\quad$ DOI: https://www.jstor.org/stable/4315023

Government of Bangladesh. 2005. Pro poor strategy for water and sanitation sector in Bangladesh. Unit for Policy Implementation (UPI), Local Government Division, Ministry of Local Government, Rural Development \& Cooperatives, Government of Peopleâs Republic of Bangladesh.

Guimaraes, J.P.C. 2002. A landscape of contracts: the organization and impact of shrimp culture in southwest Bangladesh. Doctoral thesis (pp. 367). International Institute of Social Studies, Hague, The Netherlands.

Halder, P.K. and Zaman, S. 2010. A term paper on impact of surge disaster on south-west coast of Bangladesh: A case study of cyclone óAILAôon polder No-5. Institute of Water and Flood Management, Bangladesh University of Engineering and Technology, Dhaka, Bangladesh.

Haq, A.H.M. 2000. Integrated wetland system for mitigation of the salinzation of southwest region of Bangladesh. Paper presented at the Eco Summit, 18-22 June, Nova Scotia, Canada.

Haque, M.A., Haque, A., and Ansari, M.S. 2010. Water, sanitation and health status of AILA affected coastal area of Bangladesh. Bangladesh Journal of Environmental Science, 19: 51-56.

Harun, M.A.Y.A., and Kabir, G.M.M. 2013. Evaluating pond sand filter as sustainable drinking water supplier in the southwest coastal region of Bangladesh. Applied Water Science, 3: 161-166. DOI:https://link.springer.com/article/10.1007/s1 3201-012-0069-7

Islam, K., and Kibria, Z. 2006. Unravelling KJDRPADB financed project of mass destruction in southwest coastal region of Bangladesh. Uttaran, Khulna.

Islam, M. N. 2015. Community based adaptation to climate change in the exposed coastal areas of Bangladesh. Proceedings of the $5^{\text {th }}$ International Conference on Water and Flood
Management (ICWFM-2015), pp. 591-598. Institute of Water and Flood Management, Bangladesh University of Engineering and Technology, Dhaka, Bangladesh.

Islam, M.A., Karim, M.R., Higuchi, T., Sakakibara, H., and Sekine, M. 2014. Comparison of the trace metal concentration of drinking water supply options in southwest coastal areas of Bangladesh. Applied Water Science, 4(2): 183191.

DOI: https://link.springer.com/article/10.1007/s13201 -013-0140-z

Islam, M.R., Ahmad, M., Huq, H., and Osman, M.S. 2006. State of the coast 2006. Integrated Coastal Zone Management Project, Water Resource and Planning Organization, Dhaka.

Islam, R.M. and Ahmad, M. (2004). Living in the coast problems, opportunities and challenges. Integrated Coastal Zone Management Project, Water Resource and Planning Organization, Dhaka.

Kumar, U., Baten, M.A., Masud, A.A., Osman, K.S., and Rahman, M.M. 2010. Cyclone AILA: one year on natural disaster to human sufferings. Dhaka: Unnayan Onneshan - The Innovators.

Mehta, L. 2003. Contexts and constructions of water scarcity. Economic and Political Weekly, 38: 5066-5072.

DOI:

https://www.jstor.org/stable/4414344

Moniruzzaman, M., and Rahman, M.A. 2011. Examine the water quality of pond sand filter (PSF): a study on Khontakata Union of Sarankhola Upazila, Bangladesh. Journal of the Bangladesh National Geographical Association, 39(1\&2): 97-108.

Moniruzzaman, M., Rahman, M.A., and Hossain, M.S. 2012. Assessing the physical condition and management system of pond sand filter (PSF) of a coastal community of Bangladesh. Journal of the Bangladesh National Geographical Association, 40(1\&2): 59-68.

Murty, T.S., and El-Sabh, M.I. 1992. Mitigating the effects of storm surges generated by tropical cyclones: a proposal. Natural Hazards, 6(3): 251-273.

NGO Forum for Public Health. 2012. Coping with coastal challenges. NGO Forum for Public Health, Dhaka, Bangladesh.

Nicholls, R.J., Wong, P.P., Burkett, V.R., Codignotto, J.O., Hay, J.E., McLean, R.F., Ragoonaden S. 
and Woodroffe, C.D. 2007. Coastal systems and low-lying areas. climate change 2007: impacts, adaptation and vulnerability. Contribution of Working Group II to the Fourth Assessment Report of the Intergovernmental Panel on Climate Change. Cambridge University Press, Cambridge.

NWMP. 2001. National water management plan (NWMP), Volume 2, Main report. Ministry of Water Resources, Government of the Peopleôs Republic of Bangladesh.

NWRPo. 1999. National water resource policy (NWRPo). Ministry of Water Resources, Government of the Peopleôs Republic of Bangladesh.

Park, K. 2015. Parkôs textbook of preventive and social medicine $\left(23^{\text {rd }}\right.$ Ed.). Banarsidas Bhanot Publishers, Jabalpur, India.

Patil, P.G., and Krishnan, M. 1998. The social impacts of shrimp farming in Nellore District, India. Aquac Asia, 3: 3-5.

PDO-ICZMP. 2004. Living in the coast: Problems, opportunities and challenges. Program Development Office for Integrated Coastal Zone Management Plan (PDO-ICZMP), Dhaka.

Rahman, M.H., Mamtaz, R., and Ferdausi, S.A. 1997. Pilot solar desalination plants in Bangladesh. In: J. Pickford, et al. (Eds.), Water and sanitation for all: Partnerships and innovations, Proceedings of $23^{\text {rd }}$ Water, Engineering and Development Centre (WEDC) International Conference, pp. 178-181. Durban, South Africa.

Safiuddin, M., and Karim, M.M. 2003. Water resources management in the remedy of groundwater arsenic contamination in Bangladesh. In: $\mathrm{T}$. Murphy and J. Guo (Eds.), Aquatic arsenic toxicity and treatment (pp. 1-17). Backhuys, Leiden.

Setu, N.N., Hossain, S., Saha, R., and Rahman, M. 2014. Natural disasters impact on the water cycle, resources, quality and human health. Proceedings of the 2nd International Conference on Civil Engineering for Sustainable Development (ICCESD) (14-16 February). Khulna University of Engineering and Technology, Khulna, Bangladesh.

Tran, P., and Shaw, R. 2012. Environment disaster linkage: An overview. In: R. Shaw and P. Tran (Eds.), Environment disaster linkage, 9: 3-14.
Emerald Group Publishing, Howard House, Wagon Lane, United Kingdom:

UISC. 2016. Union information service center (UISC). Kamarkhola, Dacope, Khulna.

UNDP. 2006. Human development report 2006- beyond scarcity: power, poverty and the global water crisis. United Nations Development Programme (UNDP). Retrieved from: http://www.undp.org/content/dam/undp/library/ corporate/HDR/2006\%20Global\%20HDR/HDR -2006-Beyond\%20scarcity-Power-poverty-andthe-global-water-crisis.pdf

Uttran. 2003. Supaeo panir sandhane: quest for safe water, pp. 3. CARE and CIDA, Satkhira, Bangladesh.

WASH United, Freshwater Action Network and WaterLex. 2012. The human right to safe drinking water and sanitation in law and policy A source book. Berlin, London and Le Grand Saconnex. Retrieved from: http://www.waterlex.org/resources/documents/R TWS-sourcebook.pdf

World Bank. 2005. Bangladesh country water resources assistance strategy - Bangladesh development series (No. 3). The World Bank Office, Washington, D.C. Retrieved from: http://siteresources.worldbank.org/BANGLAD ESHEXTN/Resources/Final_Water_CASprint_version.pdf

World Bank. 2016. World development indicators: Improved water sources - Bangladesh. Retrieved from: http://databank.worldbank.org/data/reports.aspx ? source $=2 \&$ series $=$ SH.H2O.SAFE.ZS\& country

World Health Organization. 2004. Occurrence of cyanobacterial toxins (Microcystins) in surface waters of rural Bangladesh - pilot study. Water, Sanitation and Health Protection of the Human Environment, World Health Organization, Geneva.

World Health Organization. 2011. Guidelines for drinking-water quality- Fourth edition. World Health Organization. Geneva. 